\title{
Identyfikacja efektów wprowadzenia innowacji społecznych oraz ich rola w rozwiązywaniu problemów stojących przed społeczeństwem
}

\author{
Kinga Gaździcka
}

\begin{tabular}{ll}
\hline Streszczenie: & Niniejszy rozdział przedstawia zagadnienie dotyczące identyfikacji efektów wprowadzenia \\
& innowacji społecznych. W pierwszej części dokonano przeglądu literatury przedmiotu, która \\
& pozwoliła przybliżyć tematykę innowaji, a także wyjaśnić ich istotę. W dalszej części rozdziału \\
& skoncentrowano się na innowacyjności w zakresie rozwiązywania problemów stojących przed \\
& społeczeństwem. W szczególności zwrócono uwagę na wykorzystanie potencjału, jaki tkwi w spo- \\
& łeczeństwie obywatelskim. Przedstawione zostały przykłady dobrych praktyk w tym obszarze, \\
& wdrożonych zarówno na poziomie lokalnym, krajowym, jak i międzynarodowy. Mogą one zostać \\
& wykorzystane do prowadzenia dalszych badań empirycznych.
\end{tabular} Słowa kluczowe: innowacje; innowacje społeczne; społeczeństwo; ekonomia; problemy społeczne; instrumenty Kody JEL: polityki społecznej $\mathrm{O} 30, \mathrm{O} 35$

\section{Wprowadzenie}

W dzisiejszych czasach w mediach pojawia się coraz więcej informacji dotyczących zwiększania się skali znaczenia innowacji społecznych oraz ich roli w rozwiązywaniu problemów stojących przed naszym społeczeństwem. Głównym celem niniejszej pracy była identyfikacja efektów wprowadzania innowacji społecznych. Podstawowym narzędziem badawczym, który przybliżył temat innowacji społecznych była literatura przedmiotu. Stanowiły ją m.in. artykuły w czasopismach, zeszyty naukowe, prace zbiorowe, fragmenty książek naukowych oraz publikacje fachowe i strony internetowe. Innowacje społeczne stanowią istotny element polityki innowacyjnej, odnoszący się do rozwiązywania problemów społecznych oraz tworzenia wartości w obszarach służących społeczeństwu. Współczesne podejście do problemu innowacji coraz wyraźniej akcentuje kontekst społeczny. Na podstawie analizy literatury przedmiotu oraz oficjalnych informacji ze źródeł Unii Europejskiej, wykazano i zidentyfikowano znaczenie innowacji społecznych oraz ich rolę w rozwiązywaniu problemów stojących przed społeczeństwem.

Występujące na świecie zmiany społeczno-gospodarcze niosą ze sobą coraz więcej problemów społecznych m.in.: bezrobocie, wykluczenie społeczne, narastające nierówności społeczne, starzejące się społeczeństwo, pogarszające się warunki życia. Obecnie ciągle wzrasta 
zanieczyszczenie środowiska, które szkodliwie wpływa na zdrowie społeczeństwa. Rozwiązanie tych problemów nie jest obowiązkiem tylko i wyłącznie rządu oraz głowy państwa. Dużą rolę odgrywa zaangażowanie lokalnych społeczności, współpraca obywateli oraz opracowywanie innowacyjnych pomysłów rozwiązywania problemów. Innowacje odgrywają istotną rolę w rozwoju gospodarczym i społecznym, stanowią narzędzie wdrożenia nowych reform społecznym m.in. w obszarze aktywizacji zawodowej, pomocy społecznej.

\section{Pojęcie i istota innowacji}

Termin innowacyjność wywodzi się z języka łacińskiego, słowo innovatio oznacza odnowienie; innovare - odnawiać (Kopaliński, 2017 s. 16). Najogólniej innowacje można zdefiniować jako „wprowadzenie czegoś nowego”. Do nauk ekonomicznych wprowadził je po raz pierwszy austriacki ekonomista Joseph Schumpeter. Traktował on innowację jako istotną zmianę funkcji produkcji, a także główny czynnik rozwoju gospodarczego. Ekonomista wyróżnił pięć przypadków innowacji (Schumpeter, 1960, s. 104):

- wprowadzenie na rynek nowatorskiego produktu, usługi;

- wdrożenie nowej metody produkcji niewypróbowanej w danej gałęzi przemysłu;

- otwarcie nowego rynku;

- pozyskanie nowego źródła surowców lub półfabrykatów;

- wdrożenie nowego sposobu organizacji danego przemysłu.

Innowacja oznacza dla Schumpetera wprowadzenie do praktyki nowego rozwiązania, nowość na skalę światową. Przede wszystkim skupia się na innowacjach technicznych i ich oddziaływaniu na gospodarkę. Badacz uważa, że jedynie pierwsze wdrożenie nowego rozwiązania można nazwać innowacją, natomiast jej rozprzestrzenianie definiuje jako imitację. Swoją koncepcję zawarł w triadzie Schumpetera (Wiśniewska, 2013, s. 11). Jeden z polskich ekonomistów - M. Kalecki - uważa innowację za nowość na skalę światową, która związana jest z rozwojem techniki, a także wprowadzaniem nowych produktów. Wdrażanie owych produktów wymaga nowych urządzeń, a także eksploatacji nowych źródeł surowców, a także nowych inwestycji związanych z produkcją i transportem (Kalecki, 1980, s. 352-353).

W literaturze ekonomicznej funkcjonuje kilka rodzajów innowacji, wśród nich wyróżniamy: techniczne, technologiczne, organizacyjne i społeczne. Innowacje techniczne dotyczą wszelkich zmian w parametrach maszyn i urządzeń, które dokonuje się poprzez wprowadzanie do nich nowych elementów, co wiąże się z ich ulepszaniem. Innowacje technologiczne pojmowane są jako zmiany w technologii procesu wytwórczego, dokonuje się ich poprzez wprowadzenie do niego nowych elementów lub całkowicie nowej technologii. Innowacje organizacyjne wyrażają zmiany schematu organizacyjnego podmiotu gospodarującego. Wynikają z całkowitej reorganizacji tego schematu lub zastąpieniu części starych elementów nowymi składnikami. Natomiast innowacje społeczne - rozumiane są jako zmiany zachodzące w strukturze społecznej ludności, we wzorach obyczajowych, kulturze narodu, postawach ludzkich. Wymienione powyżej rodzaje innowacji związane są z różnymi sferami życia, jednak nie są od siebie odrębne, funkcjonują obok siebie, uzupełniają się. Ich współzależność jest następstwem ścisłych powiązań różnych dziedzin nauki, np. nauk ekonomicznych i humanistycznych. „Innowacje w technice wytwarzania przyczyniają się do innowacji technologicznych dzięki modernizacji i unowocześnieniu bazy wytwórczej, która ma bezpośredni wpływ na technologię wytwarzania. Pociąga to za sobą potrzebę zmian w zakresie organizacji działań, a czasem także w dziedzinie struktur organizacyjnych przedsiębiorstwa i jednostek administracyjnych związa- 
nych z innowacją. Efekty zmian organizacyjnych, technicznych i technologicznych wpływają z kolei na styl życia ludzi i ich obyczaje. Tworzą nową kulturę społeczną. Ta zaś, wraz z dalszym postępem w nauce i wiedzy, sprzyja powstawaniu nowych idei, pomysłów innowacyjnych, a także upowszechnianiu istniejących innowacji" (Olejniczuk-Merta, 2013, s. 24).

\section{Geneza innowacji społecznych}

W ujęciu społecznym oraz ekonomicznym R. Praszkiera i A. Nowaka (2012) innowacje społeczne zdefiniowano jako „nowe idee, które mają rację bytu” i „pozwalają na osiąganie celów społecznych", które odróżniają innowacje od ulepszeń. Innowacje społeczne to również tworzenie i wdrażanie nowych idei w zakresie organizowania działalności międzyludzkiej lub stosunków społecznych w celu osiągnięcia wspólnych celów. Mianem innowacji społecznych możemy określić nowe działania społeczne, mające na celu polepszenie jakości życia osób, narodów, całych społeczności. Owa nowość może wynikać z wprowadzania unikalnych rozwiązań, ale także z faktu wdrożenia już znanego rozwiązania, występującego w nowym kontekście społecznym. Za innowację społeczną uznaje się także popularyzowanie i upowszechnianie zmian innowacyjnych (Olejniczuk-Merta, 2013, s. 28). Zgodnie z definicją Narodowego Centrum Badań i Rozwoju innowacje społeczne to „rozwiązania, które równocześnie odpowiadają na zapotrzebowanie społeczne, jak i powodują trwałą zmianę w danych grupach społecznych. Te rozwiązania mogą wiązać się z innowacyjnymi produktami, usługami bądź procesami, które umożliwiają odmienne rozwiązywanie typowych problemów społecznych" (NCBiR, 2013).

Innowacje wpływają na powstanie oraz rozwój nowych technologii, rozwiązań oraz na wzrost konkurencyjności przedsiębiorstw. Zmienność otoczenia wymaga od podmiotów gospodarczych określonych działań m.in. podążania za oczekiwaniami klientów, a także odpowiedniej reakcji na zmiany społeczne. Ogólna definicja ukazuje innowacje społeczne jako „nowe rozwiązanie problemu społecznego, które jest bardziej wydajne, skuteczne, trwałe czy sprawiedliwe od istniejących rozwiązań, a korzyści z tej innowacji przypadają przede wszystkim społeczeństwu jako całości, a nie osobom prywatnym" (Phills i in., 2008). Na podstawie przytoczonej definicji można zatem identyfikować nowe rozwiązania jako innowacje społeczne. Innowacje powstają często przypadkiem jako wartość dodatkowa, wynikająca z rozwoju technologii. Stają się determinantami przemian społecznych, kulturowych, demograficznych. Czynnikiem wpływającym na tworzenie innowacji jest obserwacja rynków, a także procesów demograficznych, czy też postaw społecznych (Szymański, 2015, s. 9). M. Harris i D. Albury (2009) stwierdzają, że innowacja społeczna może być efektem działania sektora publicznego, prywatnego, non-profit, a także społeczności lokalnej oraz pojedynczych jednostek. Głównym celem innowacji społecznych jest skupienie się na podniesieniu jakości życia całego społeczeństwa, a nie tylko jego wybranych grup. Innowacje społeczne mają czasami charakter względny. Często to, co w jednym środowisku jest niczym niezwykłym, odtworzone w innym staje się innowacyjne. Innowacje powinny dotyczyć realnych potrzeb, a nie tylko pragnień. Powstają wokół problemów społecznych, więc często źródłem pomysłów są ludzie, a najczęściej ci, do których adresowana jest pomoc.

Ważnym aspektem strategii rozwoju Unii Europejskiej oraz jej krajów członkowskich jest wspieranie innowacji społecznych. Według Komisji Europejskiej innowacje społeczne oznaczają opracowywanie nowych pomysłów, usług i modeli w celu lepszego rozwiązywania problemów społecznych. Przejawiają się one także zachęcaniem podmiotów publicznych i prywatnych, w tym społeczeństwa obywatelskiego, do wnoszenia wkładu w poprawę usług 
socjalnych. Według OECD innowacje społeczne "(...) nie odnoszą się do wprowadzenia nowych rodzajów produkcji lub wykorzystywania nowych rynków ze względu na ich wykorzystanie (dla zysku), ale ich głównym celem jest zaspokojenie nowych potrzeb, nie dostarczanych przez rynek (nawet jeśli rynki interweniują później) lub tworzenie nowych, bardziej satysfakcjonujących sposobów aktywizacji, dając ludziom miejsca pracy i zmieniając ich role w procesie produkcji" (Wronka-Pośpiech, 2015, s. 127-128).

W projekcie TEPSIE (Theoretical, Empirical and Policy Foundations for Social Innovation in Europe) poprzez innowacje społeczne rozumie się nowe rozwiązania, które mają na celu zaspokojenie potrzeb społecznych, a także doprowadzają do nowych lub ulepszonych zdolności sprawczych społeczeństwa oraz całkowitego wykorzystania posiadanych zasobów. Wronka-Pośpiech (2015) w swojej publikacji wybrała i zestawiła przykładowe typy innowacji społecznych na postawie TEPSIE:

- nowe produkty - technologie wspomagające ludzi niepełnosprawnych (np. syntezatory głosu);

- nowe usługi - mikrokredyty, bankowość mobilna;

- nowe procesy - model współpracy peer-to-peer, crowdsourcing;

- nowe rynki - Fair Trade, banki czasu;

- nowe platformy - nowe modele opieki nad osobami z niepełnosprawnością intelektualną i będącymi w „społecznej izolacji”;

- nowe formy organizacyjne - przedsiębiorstwa społeczne;

- nowe modele biznesowe - franczyza społeczna, wykorzystanie strategii JIT (just-in-time) przy wyzwaniach społecznych.

Proces opracowywania innowacji społecznych można podzielić na sześć etapów. W literaturze przedmiotu najczęściej wykorzystywany jest ten opracowany przez Murraya, Caulier-Gricea i Mulgana. Autorzy zaznaczają, że etapy nie zawsze następują po sobie bezpośrednio, a pomiędzy nimi musi zachodzić sprzężenie zwrotne.

Pierwszy z nich stanowią „inspiracje” (prompts), które mają odniesienie do potrzeb społecznych, inspiracją mogą być problemy związane z kryzysem gospodarczym, klęski żywiołowe, lub zmiany demograficzne, np. starzenie się społeczeństwa, bezrobocie. Drugi etap „propozycje” (proposals) zawiera pomysły dotyczące rozwiązywania problemów społecznych, pomysły te mogą pochodzić od społeczności lokalnej, obywateli. Pomocnym narzędziem służącym do gromadzenia pomysłów stanowi jedna z metod heurystycznych m.in. burza mózgów. W trzecim etapie zwanym „prototypem” (prototyping) zgromadzone pomysły podlegają ocenie. Otrzymuje się odpowiedź zwrotną wraz z informacją dotyczącą ich celowości i użyteczności. Czwarty etap - „utrzymanie” (sustaining) koncentruje się na metodach oceny innowacji. Dla pomysłów innowacyjnych, które zostały zaakceptowane, opracowywane są modele biznesowe. Modele, aby zapewnić stabilność, powinny uwzględniać stronę finansową i prawną przedsięwzięcia. Etap piąty - „skalowanie” (scaling) stanowi dyfuzję innowacji wśród społeczności, jego celem jest zwiększenie zasięgu i wpływu innowacji poprzez jej ekspansję. Ostatni etap - "zmiana systemowa” (systemic change) to wprowadzenie w życie nowych sposobów działania. Dotyczą one m.in. strategii, modeli biznesowych, przepisów prawnych, powołania do życia nowych organizacji. Inicjują trwałą zmianę społeczną będącą ostatecznym celem innowacji społecznych. Zmiany systemowe to innowacje społeczne, które doprowadziły do zmian w systemie edukacyjnym, zdrowotnym i wpłynęły pozytywnie na zachowania ludzi (Kroik i Skonieczny, 2014, s. 165-166). Aby innowacja mogła być uznana za innowację społeczną, powinna wyróżniać się atrybutami takimi jak: nowość (innowacje muszą stanowić 
nowość w wybranej dziedzinie), pomysłowość (tylko nieliczne wynalazki stają się innowacjami, później mogą być inspiracją do nowych idei), skuteczność (wartością innowacji społecznej jest jej efektywność), spełnienie potrzeby społecznej (cechą innowacji społecznej jest realizacja potrzeby społecznej), zwiększenie aktywności społecznej do działania (proces innowacji powinien zwiększać aktywność społeczeństwa) (Wacławski, 2017, s. 459-460).

\section{Przykłady innowacji społecznych}

W Europie od 2013 r. organizowany jest Europejski konkurs na innowacje społeczne (European Social Innovation Competition) ku pamięci Diogo Vasconcelosa. Konkurs prowadzony jest przez Komisję Europejską we wszystkich krajach stowarzyszonych w ramach programu „Horyzont 2020". Swoją koncepcją zachęca wszystkich Europejczyków do znalezienia rozwiązań problemów dotykających nasze społeczeństwo. Konkurs skierowany jest do każdego, a jego celem jest wyszukanie i promocja najciekawszych pomysłów na innowacje społeczne oraz wsparcie najlepszych z nich w ich transformacji w konkretne projekty i rzeczywiste przedsięwzięcia. Główną nagrodą dla zwycięzcy jest 50000 euro, a także wsparcie i realizacja projektu. W latach 2015-2017 konkurs był organizowany we współpracy z: NESTA, Fundacją Kennisland, Pracownią Badań i Innowacji Społecznych "Stocznia”, siecią ImpactHub, firmą Matter\&Co (European Commission, 2019). Na oficjalnej stronie internetowej EUSIC (The European Social Innovation Competition) mamy dostęp do szeregu informacji dotyczących zasad przeprowadzenia konkursu, nagród, terminu zgłoszeń, a także szczegółów dotyczących poprzednich edycji konkursu. Każda edycja skupiała się na gromadzeniu pomysłów na rozwiązanie kluczowych problemów stojących przed naszym społeczeństwem:

- 2013 r.: New forms of work local, pierwsza edycja dotyczyła przełomowych pomysłów dotyczących nowych sposobów tworzenia większej liczby lepszych miejsc pracy w Europie;

- 2014 r.: The job challenge, druga edycja została poświęcona pomysłom na tworzenie przełomowych rodzajów pracy w celu zaspokojenia potrzeb społecznych. Jeden ze zwycięskich pomysłów dotyczył zaangażowania kobiet niepełnosprawnych w szycie nowych projektów z lekko uszkodzonych materiałów;

- 2015 r.: New ways to grow, w tej edycji poszukiwano innowacji społecznych, które mogą przyczynić się do budowania fundamentów dla bardziej zrównoważonego i sprzyjającego społeczeństwu modelu wzrostu w Europie. Poszukiwano projektów demonstrujących nowe modele wzrostu ukierunkowane na lepszą jakość życia obywateli oraz działania rządu i przedsiębiorstw;

- 2016 r.: Integrated futures, pomysły na innowacje społeczne związane były z migrantami i uchodźcami. Głównie pozyskiwano rozwiązania zarówno w postaci konkretnych produktów, technologii, ale także usług czy modeli, które mogą wspomagać proces integracji imigrantów i uchodźców;

- 2017 r.: Equality rebooted, skupiono się na pomysłach dotyczących wyrównywania szans związanych z korzystaniem z nowych technologii, a także nad zastosowaniem narzędzi ICT w wyrównywaniu szans życiowych różnych grup społecznych;

- 2018 r.: Re:Think, w tej edycji poszukiwano rozwiązań angażujących młodych ludzi w lokalną gospodarkę: produktów, usług, rozwiązań biznesowych wzmacniających pozycję młodych na rynku pracy o stale zmieniającej się koniunkturze. W sposób szczególny wyróżniono działania promujące stałe i wartościowe zatrudnienie młodych osób, czyli dające szansę na rozwój zawodowy; 
- 2019 r.: Challenging plastic waste, w tej edycji Europejski Konkurs Innowacji Społecznych poszukuje pomysłów i projektów, które ograniczają odpady i zaśmiecanie poprzez zmianę i ulepszenie istniejących procesów lub wprowadzenie zupełnie nowych produktów i inicjatyw. Innowacje te muszą zmniejszyć ilość tworzyw sztucznych lub zachęcić i umożliwić ponowne wykorzystanie i recykling odpadów z tworzyw sztucznych. Temat powinien dotyczyć jednego z przedstawionych obszarów: zmniejszenie zużycia jednorazowych produktów z tworzyw sztucznych, ponowne użycie i recykling istniejących odpadów z tworzyw sztucznych, postępowanie z nagromadzonymi odpadami z tworzyw sztucznych na składowiskach i w środowisku, zmiana zachowań konsumenckich, sprzedaży detalicznej i szerszych praktyk biznesowych w celu zmniejszenia ilości odpadów z tworzyw sztucznych i/lub zwiększenia recyklingu i ponownego użycia, wdrażania alternatywnych modeli biznesowych i optymalizacja łańcuchów dostaw w celu zmniejszenia ilości odpadów z tworzyw sztucznych i/lub zwiększenia recyklingu i ponownego użycia, opracowanie nowych materiałów nadających się do gospodarki o obiegu zamkniętym lub oferujących zrównoważone alternatywy dla tworzyw sztucznych na bazie paliw kopalnych.

Każda z edycji Europejskiego konkursu na innowacje społeczne wyłoniła innowacyjne pomysły, które zostały przekształcone w konkretne projekty, a następnie w rzeczywiste przedsięwzięcia biznesowe. Poprzez konkurs wsparte zostały kreatywne idee, które zmieniły sposób funkcjonowania i współdziałania europejskich gospodarek i społeczeństw.

Oprócz międzynarodowych innowacji społecznych pojawiają się lokalne, które pomagają w rozwiązaniu lokalnych problemów. Jedną z nich stanowi "Społeczne mapowanie przestrzeni", które polega na zaznaczeniu na wirtualnej mapie punktów (odzwierciedlających problemy) w przestrzeni (miasta, dzielnicy itd.). Problemy mogą dotyczyć na przykład uszkodzonej infrastruktury drogowej, niedziałającej sygnalizacji świetlnej. Każda osoba, która dostrzeże w swoim otoczeniu problem może przez stronę internetową zaznaczyć go na mapie i krótko opisać. Informacja ta od razu trafia do urzędników usprawniając ich pracę i angażując mieszkańców. W Polsce przykładem mapowania jest portal www.naprawmyto.pl, który umożliwia użytkownikom zgłaszanie zaobserwowanych problemów. Kategorie alertów dotyczą: infrastruktury, bezpieczeństwa, budynków, przyrody. Głównym zadaniem mapowania jest ułatwienie komunikacji pomiędzy mieszkańcami a samorządem, które pomaga wspólnie naprawiać otoczenie. Mieszkańcy mogą zaproponować wszelkiego rodzaju rozwiązania i mogą poczuć się bardziej związani ze swoim miastem, mając realny wpływ na jego rozwój i zmiany. Kolejnym przykładem lokalnej innowacji stanowi projekt „Lokalni badacze szukają błędów systemu pomocy socjalnej". Projekt powstał w Londynie i polegał na rekrutowaniu wśród lokalnej społeczności „badaczy społecznych”. Badacze mieli dostęp do grup potrzebujących pomocy lub tych, których pomoc socjalna pomija. W ten sposób mogli poznać realne potrzeby odbiorców oraz wady istniejącego systemu pomocy. Efekty pracy pomagają zreformować pomoc socjalną oraz społeczną, a także sprzyjają aktywności mieszkańców (Kamocka, 2015).

Innowacje stały się odpowiedzią na liczne problemy i kryzysy społeczne zachodzące w Unii Europejskiej. Wymaga to podjęcia ryzyka i poszukiwania nowych sposobów, które pozwolą szybciej rozwiązywać problemy. Program Wiedza Edukacja Rozwój jest jednym ze źródeł finansowania innowacji społecznych w Polsce. Na jego cel przewidziano blisko 1 mld zł. Jeden z projektów innowacyjnych, które miały wpływ na nowe rozwiązania systemowe to "W poszukiwaniu polskiego modelu ekonomii społecznej". Powstał w celu zaangażowania społeczności lokalnej na rzecz wykorzystania instrumentów gospodarki społecznej w aktywizacji zawodowej grup zagrożonych wykluczeniem z rynku pracy. Natomiast „Dzienna Mama” to projekt, 
który miał na celu zainicjowanie zmiany w obszarze godzenia życia zawodowego z rodzinnym (Ministerstwo Funduszy i Polityki Regionalnej, 2015). Dzienna Mama to osoba, która opiekuje się dziećmi kobiet pracujących. Musi przejść przez szereg badań psychologicznych i lekarskich, a także uczestniczyć w szkoleniach pedagogicznych i psychologicznych, które pomagają w opiece nad dziećmi. Program pomaga pracującym rodzicom, zwłaszcza kobietom, od których współczesny rynek pracy wymaga ciągłego podnoszenia kwalifikacji, wyjazdów na szkolenia, a także pracy w nadgodzinach. Projekt realizowany przy udziale środków Europejskiego Funduszu Społecznego, budżetu państwa i w ramach Inicjatywy Wspólnotowej EQAUL (Usługa..., 2007, s. 1).

„Banki czasu” to jedna z innowacji społecznych, której mechanizm opiera się na wzajemnej pomocy poprzez bezgotówkową wymianę usług. Każdy z uczestników posiada w banku konto, na które spływają „dolarogodziny" za każdą udzieloną pomoc. Gdy sami potrzebują pomocy mogą wykorzystać zgromadzone "fundusze” i zapłacić za usługę. Jednostkę płatniczą stanowią godziny. Banki zrzeszają członków o różnych umiejętnościach. Najczęściej oferowanymi usługami są: naprawa sprzętu, korepetycje, wyprowadzanie psów, opieka nad dziećmi, robienie zakupów. Banki czasu wspierane są przez fundusze unijne, za które m.in. przeprowadzane są szkolenia. Znaczna część banków czasu zakładana jest przez organizacje pozarządowe i opiera się na zasadzie sprawiedliwości społecznej (Szczepańska, 2017, s. 222).

Obecny rozwój technologii wpłynął na zwiększenie popularności handlu internetowego w Polsce. Coraz większa liczba Polaków (ponad 60\%) korzysta z Internetu w domu. Wzrost popularności handlu internetowego, e-biznesu, e-administracji generuje potrzebę powstawania innowacyjnych rozwiązań ułatwiających lub polepszających jakość usług. W sektorze handlu internetowego użytkownicy wykorzystują innowacje w celu uzyskania korzyści w postaci poprawy jakości procesu zakupu. Poniżej zestawiono najpopularniejsze przykłady:

- serwis Groupon, który opiera się na dostarczaniu użytkownikom ofert promocyjnych na usługi i produkty. Największą korzyścią dla użytkowników są niższe ceny produktów w porównaniu do alternatywnych form sprzedaży. Zakupy grupowe są zarówno innowacją społeczną oraz marketingową;

- porównywarka cen, która umożliwia klientom uzyskanie zestawienia najlepszych i najtańszych ofert np. Skąpiec, Ceneo;

- innowacyjne formy płatności m.in. Mikropłatności SMS, elektroniczne portmonetki oraz szybkie przelewy zyskują popularność wśród e-klientów. Szybkie przelewy są łatwe w obsłudze oraz szybsze w realizacji niż te w klasycznej formie;

- logistyka handlu elektronicznego. Wśród dostaw od wielu lat najpopularniejszą firmą jest Poczta Polska, jednak ze względu na ograniczenia dotyczące godzin odbioru przesyłek opracowano nowe rozwiązanie. Firma In-post wprowadziła paczkomaty, czyli system automatycznych skrytek pocztowych służący do nadawania i odbierania przesyłek. Umożliwiają one odbiór przesyłek 24h na dobę. Największą zaletą jest liczba paczkomatów w całej Polsce oraz ich dogodna lokalizacja (Szymański, 2015, s. 11-15).

Przedstawione przykłady innowacji społecznych związanych z e-handlem ukazują, że stają się one coraz bardziej popularne w Polsce. Przedsiębiorstwa wprowadzając innowacje dostrzegają szanse pozyskania nowych klientów w celu zwiększenia swojej konkurencyjności. Innowacje społeczne umożliwiają e-klientom usprawnioną obsługę procesu zakupowego, natomiast sklepy internetowe kreują swój wizerunek jako nowoczesnej firmy.

W polskich miastach coraz większym problemem stają się korki, niewystarczająca liczba miejsc parkingowych, duże zanieczyszczenie powietrza, smog. Innowacyjnym rozwiązaniem 
w tej kwestii stał się carpooling. Inicjatywa polegająca na kojarzeniu osób udających się w tym samym kierunku i zachęcaniu ich do wspólnej podróży jednym samochodem. Korzyścią owej usługi jest przede wszystkim ograniczenie natężenia ruchu kołowego, zmniejszającego jednocześnie korki oraz zanieczyszczenie środowiska. Działanie wspierane jest przez aplikacje mobilne m.in: carpooling, blablacar. Podobną innowacją są rowery miejskie oraz hulajnogi elektryczne. System ten polega na wypożyczaniu sprzętu, który staje się dogodnym sposobem transportu w zatłoczonych centrach miast. Niewielka opłata oraz ogólnodostępność sprzyja wzrostowi popularności powyższej innowacji (Szczepańska, 2017, s. 223-224).

\section{Podsumowanie}

W dzisiejszym coraz bardziej złożonym i zmiennym świecie, wraz z tempem rozwoju technologicznego wciąż rosną problemy społeczne. Ich rozwiązanie wymaga innowacyjnych pomysłów i zaangażowania wielu podmiotów. Innowacje społeczne to rozwiązanie, które w innowacyjny i skuteczny sposób zaspokaja potrzeby społeczne, rozwiązując problemy społeczne i zwiększając zdolność obywateli do działania. Znacząco wpływają na rozwój lokalny i regionalny. Są stosowane w takich obszarach jak: opieka zdrowotna, energia odnawialna, środowisko, poprawa życia biednych i wykluczonych. Innowacjami społecznymi mogą być: nowe produkty, usługi, procesy, rynki, modele biznesowe, formy organizacyjne. Innowacje społeczne przynoszą korzyści społeczności pod względem materialnym, społecznym, edukacyjnym i moralnym. Dzięki ich głównej funkcji rozwiązywania problemów społecznych umożliwiają lepsze wykorzystanie potencjału społeczeństwa obywatelskiego. W swoim zakresie obejmują różne poziomy życia społecznego, zarówno w skali lokalnej, jak i globalnej. W procesie ich powstawania oraz wdrożenia biorą udział twórcy oraz odbiorcy innowacji, przez co innowacje społeczne stają się działaniem zbiorowym. Zaangażowane są różne środowiska, więc twórcami innowacji społecznych są zarówno indywidualne podmioty, jak i grupy (Kruk, 2016, s. 85).

Rozdział ten miał na celu identyfikację efektów wprowadzenia innowacji społecznych. Jak można zauważyć, jest wyraźna siła i zakres oddziaływania innowacji społecznych oraz ich znacząca rola w rozwiązywaniu problemów stojących przed społeczeństwem. Przytoczona literatura wykazała, że wprowadzanie innowacji przynosi pozytywne efekty na całym świecie. W sytuacji pojawienia się kryzysu gospodarczego kraju oraz problemów społecznych, np. deficytu opieki nad osobami niepełnosprawnymi, zwiększonej migracji, innowacje społeczne sprzyjają tworzeniu przedsięwzięć i projektów, które stanowią rozwiązanie problemów określonego społeczeństwa. Wymaga to jednak postawy otwartości, bycia aktywnym podmiotem życia społecznego, a także zaangażowania i wychodzenia z własną inicjatywą członków społeczeństwa. Tylko zaangażowanie możliwie jak największej części mieszkańców danego kraju czy określonego regionu pozwoli stworzyć i wykorzystać innowacje społeczne w celu rozwiązania problemów stojących przed naszym społeczeństwem.

\section{Literatura}

European Commission (2015). Social innovation. Pobrane z: https://ec.europa.eu/social/main.jsp?catld=1022\& langld=en (dostęp: 10.05.2019).

European Commission (2019). 2020 theme: Reimagine Fashion - changing behaviours for sustainable fashion. Pobrane z: https://ec.europa.eu/growth/industry/innovation/policy/social/competition (dostęp: 12.05.2019). 
Harris, M., Albury, D. (2009). Why radical innovation is needed to reinvent public services for the recession and beyond: The innovation imperative. London: The Lab Discussion Paper, NESTA.

Kalecki, M. (1980). Kapitalizm. Dynamika gospodarcza, t. 2. Warszawa: Państwowe Wydawnictwo Ekonomiczne.

Kamocka, I. (2015). Innowacje społeczne w rozwiązywaniu problemów w miastach. Pobrane z: http://clubbingeurope.schuman.pl/pl/materialy/3339-innowacje-spoleczne-w-rozwiazywaniu-problemow-wmiastach (dostęp: 20.05.2019).

Kopaliński, W. (2007). Słownik wyrazów obcych i zwrotów obcojęzycznych z almanachem. Warszawa: Oficyna Wydawnicza Rytm.

Kroik, J., Skonieczny, J. (2014). Innowacja społeczna a społeczna odpowiedzialność przedsiębiorstwa. Pobrane z: www.ptzp.org.pl/files/konferencje/kzz/artyk_pdf_2013/p014.pdf (dostęp: 15.05.2019).

Kruk, M.S. (2016). Innowacje społeczne odpowiedzią na lokalne problemy współczesnego społeczeństwa. Opuscula Sociologica, 2(16), 75-88.

Ministerstwo Funduszy i Polityki Regionalnej (2015). Innowacje społeczne w Polsce. Warszawa: Ministerstwo Funduszy i Polityki Regionalnej: www.power.gov.pl/strony/wiadomosci/innowacje-spoleczne-w-polsce (dostęp: 23.05.2019).

NCBiR (2013). Program Innowacje Społeczne. Warszawa: Narodowe Centrum Badań i Rozwoju. Pobrane z: www. ncbr.gov.pl/fileadmin/gfx/ncbir/userfiles/_public/programy_krajowe/innowacje_spoleczne/opis_programu_is_1.pdf (dostęp: 10.05.2019).

Olejniczuk-Merta, A. (2013). Innowacje społeczne. Konsumpcja i Rozwój, 1(4), 24-28.

Phills Jr., J.A., Deiglmeier, K. and Miller, D.T. (2008) Rediscovering Social Innovation. Stanford Social Innovation Review, 6(34), 34-43.

Pracownia Badań i Innowacji Społecznych „Stocznia” (2017). Europejski konkurs na innowacje społeczne. Pobrane z: https://stocznia.org.pl/projekty/europejski-konkurs-na-innowacje-spoleczne/ (dostęp: 15.05.2019).

Schumpeter, J.A. (1960). Teoria rozwoju gospodarczego. Warszawa: PWN.

Szczepańska, M. (2017). Innowacje społeczne w polskich miastach, W: A. Kaszkur, A. Laska. (red.). Innowacyjność w warunkach współczesnych miast (s. 222-224). Bydgoszcz: Wydawnictwo UKW.

Szymański, G. (2015). Innowacje społeczne w polskim sektorze e-commerce, W: M. Szczepańczyk (red.). Innowacje społeczne w teorii i praktyce (s. 8-17). Łódź: Wydawnictwo Politechniki Łódzkiej.

Usługa "Dzienna mama” (2007). Nowości Grudziqdzkie. Dodatek z dnia 24.04.2007. Pobrane z: www.equal.org.pl/ download.php?Mod=biuro\&FID=116 (dostęp: 15.05.2019).

Wacławski, Z. (2017). Rola innowacji społecznych w rozwoju regionu województwa lubelskiego - przykłady dobrych praktyk, Nierówności Społeczne a Wzrost Gospodarczy, 50, 459-460.

Wiśniewska, S. (2013). Skuteczność niekomercyjnych instytucji otoczenia biznesu we wspieraniu innowacji marketingowych małych i średnich przedsiębiorstw. Kraków: Uniwersytet Ekonomiczny w Krakowie.

Wronka-Pośpiech, M. (2015). Innowacje społeczne - pojęcie i znaczenie. Studia Ekonomiczne, 212, 124-136.

\title{
Identification of the effects of introducing social innovations and their role in solving problems facing society
}

Summary: This chapter is dedicated to the topic of effects of social innovation. The first part of the paper reviews the existing literature on the subject of innovation. The remaining part of the study focuses on the effectiveness of innovation in solving problems facing society. In particular, attention has been paid to exploiting the potential of civil society. The paper presents a selection of best practices in this area, implemented at local, national and international levels. The presented cases can serve as benchmarks for further empirical research.

Keywords: innovations; social innovation; society; economy; social problems; instruments social policy JEL codes: O30, O35

\section{Informacje o autorze}

\author{
Kinga Gaździcka \\ Fundacja Gospodarki i Administracji Publicznej \\ ul. ks. bp. Wł. Bandurskiego 58/11, 30-050 Kraków \\ e-mail: kingaa.g@interia.pl
}




\section{Prawa autorskie i licencja / Copyright and License}

(c) $(1) \Theta$

Publikacja na licencji Creative Commons Uznanie autorstwa -

Użycie niekomercyjne - Bez utworów zależnych 4.0 Międzynarodowe (CC BY-ND 4.0)

http://creativecommons.org/licenses/by-nc-nd/4.0/deed/pl

This work is published under the terms of the Creative Commons

Attribution - NoDerivetives International (CC BY-ND 4.0) License http://creativecommons.org/licenses/by-nc-nd/4.0

Wydane przez Uniwersytet Ekonomiczny w Krakowie. Małopolska Szkoła Administracji Publicznej

Published by Cracow University of Economics - Krakow, Poland. Małopolska School of Public Administration of the Cracow University of Economics 